УДК 34(478)

JEL C1, D81

STEPANOV V.N.

Dr. Econ. Sciences, Prof.

Chief researcher

Institute Of Market Problems And Economic\&Ecological Researches of the

National Academy Of Sciences Of Ukraine

Frantsuzskiy Boulevard, 29, Odessa, Ukraine, 65044

e-mail: e-mail: stepanovipreei@gmail.com

HTTPS://ORCID.ORG/0000-0001-5432-1115

\title{
"CHALLENGE" AS A FUNDAMENTAL CATEGORY OF THE NATIONAL SECURITY AND RISKOLOGY
}

Topicality. At present, the problem of methodological and methodical comprehension of the category "challenge" as a phenomenon of complex unstable processes of modern social development is actualized. Professionals dealing with national security issues and responding to challenges and risks posed by them today are particularly aware of the need to create a new potential for modern security management theory and methodology.

Aim and tasks. The aim of the work is to discuss topical issues of system presentation and formalization of the "challenge" as a functional category of modern riskology and the theory of national security.

Research results. Formed some theoretical and methodological basis of the systematic presentation of modern challenges as a source of risk situations, including an extraordinary (critical) character. It is noted that the progress of science and economic development, the exacerbation of socio-economic, resource-ecological and other contradictions and conflicts generate serious challenges and threats to the person and environment of his residence.The paper considers the results of the conceptual-categorical representation of the "challenge" and its derivatives from the perspective of the parametric general theory of systems. The place and role of the "challenge" in the system of risk management and national security are discussed. Particular attention is paid to the problem of "risk" as a consequence of calls and as an important category of risk management theory.

Conclusions.The results of the theoretical and methodological comprehension of the "call" from the positions of the system-parametric approach presented in the paper are a definite basis for the formation of the conceptualcategorical basis of development and the theory of national security and riskology.

In this context, the concept-categorical design of the "challenge" is seen as cumulative, purposeful or random changes in social development, which can lead to both negative and positive synergetic effects; specially formed new ideas, projects that determine the new transformation processes; new threats, new opportunities that affect the essential (indigenous) interests of communicatively dependent economic and other actors, and require, as a rule, urgent response.

Keywords. Challenge, risks, risk management, national security, system-parametric approach, research methodology.

СТЕПАНОВ В.М.

доктор економічних наук, професор, головний науковий співробітник

Інститут проблем ринку та економіко-екологічних досліджень НАН Украӥни

Франиузький бульвар, 29/2, м. Одеса, Україна, 65044

e-mail: stepanovipr@gmail.com

HTTPS://ORCID.ORG/0000-0001-5432-1115

\section{«ВИКЛИК» ЯК ФУНДАМЕНТАЛЬНА КАТЕГОРІЯ ТЕОРІЇ НАЦІОНАЛЬНОЇ БЕЗПЕКИ І РИЗИКОЛОГІї}

Актуальність. В даний час актуалізується проблема методологічного $і$ методичного осмислення категорії «виклик» як феномена складних нестійких прочесів сучасного суспільного розвитку. Професіонали, які займаються проблемами наџіональної безпеки і реагування на виклики та породжувані ними ризики в даний час з особливою гостротою усвідомлюють необхідність формування нового потенціалу сучасної теорії $i$ методологї управління безпекою.

Мета та завдання. У роботі ставиться мета обговорити актуальні питання формування наукових основ системного уявлення і формалізації «виклику» як фундаментальної категорії сучасної ризикології $і$ теорії національної безпеки, удосконалення системи управління ризиками. 
Ця мета зумовлює необхідність постановки певного комплексу задач $і$ нового міждисциплінарного підходу до обтрунтування управлінських рішень по забезпеченню безпеки.

Результати. Сформований деякий теоретико-методологічний базис системного уявлення сучасних викликів як джерела ризикових ситуацій, в тому числі надзвичайного (критичного) характеру. Відзначається, щцо прогрес науки та економічного розвитку, загострення соціально-економічних, ресурсно-екологічних та інших протиріч $і$ конфліктів породжують серйозні виклики та загрози людині та середовищу його проживання. У роботі розглядаються результати понятійно-категоріального уявлення «виклику» $i$ його похідних з позицій параметричної загальної теорії систем. Обговорюються місие і роль "виклику» в системі управління ризиками і національною безпекою. Особлива увага звертається проблеми "ризику» як наслідок викликів і як важливої категорії теорї̈ управління ризиками.

Висновки. Представлені в роботі результати теоретико-методологічного осмислення «виклику» 3 позицій системно-параметричного підходу є певною основою формування понятійно-категоріального базису теорії розвитку, теорї національної безпеки, і ризикології.

В изьому контексті понятійно-категоріальна конструкиія «виклик» розглядається як кумулятивні, цілеспрямовані або випадкові зміни у суспільному розвитку, які можуть приводити як до негативних, так $i$ позитивних синергетичних ефектів; спеціально сформовані нові ідеї, проекти, які обумовлюють нові трансформаційні прочеси; нові небезпеки (загрози), нові можливості, щзо зачіпають істотні (корінні) інтереси комунікаційно залежних суб'єктів економічних та інших відносин, і вимагають, як правило, невідкладного реагування.

Ключові слова. Виклик, ризики, управління ризиками, національна безпека, системно-параметричний підхід, методологія дослідження.

Introduction. Since the second half of the twentieth century there has been an increasing interest of scientists and managers in the problem of threats and dangers of economic, ecological, technogenic, militarypolitical and other nature, which in their integrated set determine the national security of the state.

In the modern science of national security, special importance is attached to the development of methodology and the theory of national security, risk management, etc. At the same time, there is a growing need for an appropriate refinement and deepening of the conceptual-categorical apparatus. Such a statement of the question, first of all, concerns such concepts as security, danger, threats, risks, damages, etc.

In this context, one should pay attention to such a category of security theory as a "challenge", which, in our opinion, is extremely important for understanding the problems of genesis and ontogeny of currently emerging threats and dangers, and for the formation of scientific bases for ensuring security.

Analysis of recent researches and publications. National security in the context of the problems of Ukraine is devoted to a fairly large number of works [1 - 3]. National security is one of the central problems of public administration aimed at ensuring the protection of the vital interests of the individual, society and the state from internal and external threats. The objects of national security management are the most diverse spheres of the state's life - socio-economic, resource-ecological, political, territorial, cultural, information, scientific and technical, etc. [4 - 6].

At present, in conditions of widespread aggravation and complication of threats and dangers in virtually all spheres of human activity, which are especially typical for modern Ukraine, the issues of the formation of a new nonclassical safety theory that takes into account the nonlinearity, instability, uncertainty and complexity of modern development processes are being actualized.

One of the important issues in the development of security theory is the formation of the conceptualcategorical apparatus corresponding to the requirements of time. These or other aspects of the formation of terms, concepts and categories in relation to the problems of research of national security problems were considered in the works of V.A. Lipkin [7, 8], V.A. Dergachev [9], etc. One of the fundamental concepts of the theory of national security - "national interests" is considered in detail in the work of B.V. Burkinsky and V.N. Stepanov [10, p. 9 - 13].

Previously unsettled problem constituent. Despite the rather large number of publications on security issues, the modern conceptual-categorical basis of the theory of security remains to some extent imperfect. In this regard, it is sufficient to point out one of the key concepts in this area, namely, "challenges (challenges)".

Aim and tasks. Proceeding from the foregoing, the aim of this article is to consider the concept of "challenge" as a fundamental category of security theory, which, firstly, would most fully describe and reflect the most significant properties and relations of the "challenge" in the system of various forms of national security; secondly, it could take place in a conceptual safety classifier as a specific type, type. 
Results. In modern dictionaries and reference books on economics, sociologists and other sciences, the concept of "challenge" does not occur. In the fundamental work of V.A. Dergachev "Geopolitical dictionary-reference book" [9, p. 96 - 97] this concept in the form of a challenge - and answer» is considered the well-known civilizational theory of the historical development of Arnold Toynbee in the multivolume work "Comprehension of history". Here, the "challenge-response" is associated with the "cycle of local civilizations", the viability of which is determined by the possibility of a consistent mastering of the living environment and the development of the spiritual principle in all types of human activity.

It should be emphasized that at the turn of the 20th - 21st centuries. the term "challenge", with the half-day of American political scientists, has received wide application, primarily in the geopolitical, geoeconomic and military-political spheres. The dynamism of modern transformational processes in social development, the conditioning of changes and the need for an adequate response predetermined the widespread use of this term.

In the work of the scientist-economist I. Petrenko [11, p. 150], an attempt is made to define the "challenge" as a factor or a set of factors and conditions, not necessarily aggressive (threatening) in nature, but requiring them to be taken into account and, accordingly, reacted on the part of the object.

In one of our works devoted to the problems of forming a theoretical and methodological basis for studying national problems, including economic and environmental security [12, p. 126] the concept of "challenge" is associated with such meaningful formulations as subjective cumulative goal-directed, deterministic or accidental changes in social development or the emergence of new ideas, projects (programs), causing new transformational processes (changes), new dangers and threats, new opportunities that affect the interests of communication-dependent objects of economic and other relations, and require an adequate response to a new situation on the part of the objects.

Below, we will try to consider a number of general and special issues in the formation of the category "challenge".

The general formalization of the security problem, taking into account the challenges and other factors of impact, can be represented as the following functional dependence for objects

$$
\mathrm{F}=\mathrm{f}\left(\mathrm{C}, \mathrm{P}, \mathrm{H}, \mathrm{T}^{\prime}, \mathrm{R}, \mathrm{N}_{\mathrm{e}}, \mathrm{D}, \mathrm{M}\right) \text {, }
$$

where: $\mathrm{C}$ - challenges, $\mathrm{P}$ - problems, $\mathrm{H}$ - hazards, $\mathrm{T}$ - threats, $\mathrm{R}$ - risks, $\mathrm{Ne}$ - negative events, $\mathrm{D}$ damages, $\mathrm{M}$ - response mechanisms (anti-crisis management system).

Graphical interpretation of this dependence is represented in the form of a "safety pyramid", shown in Fig. 1.

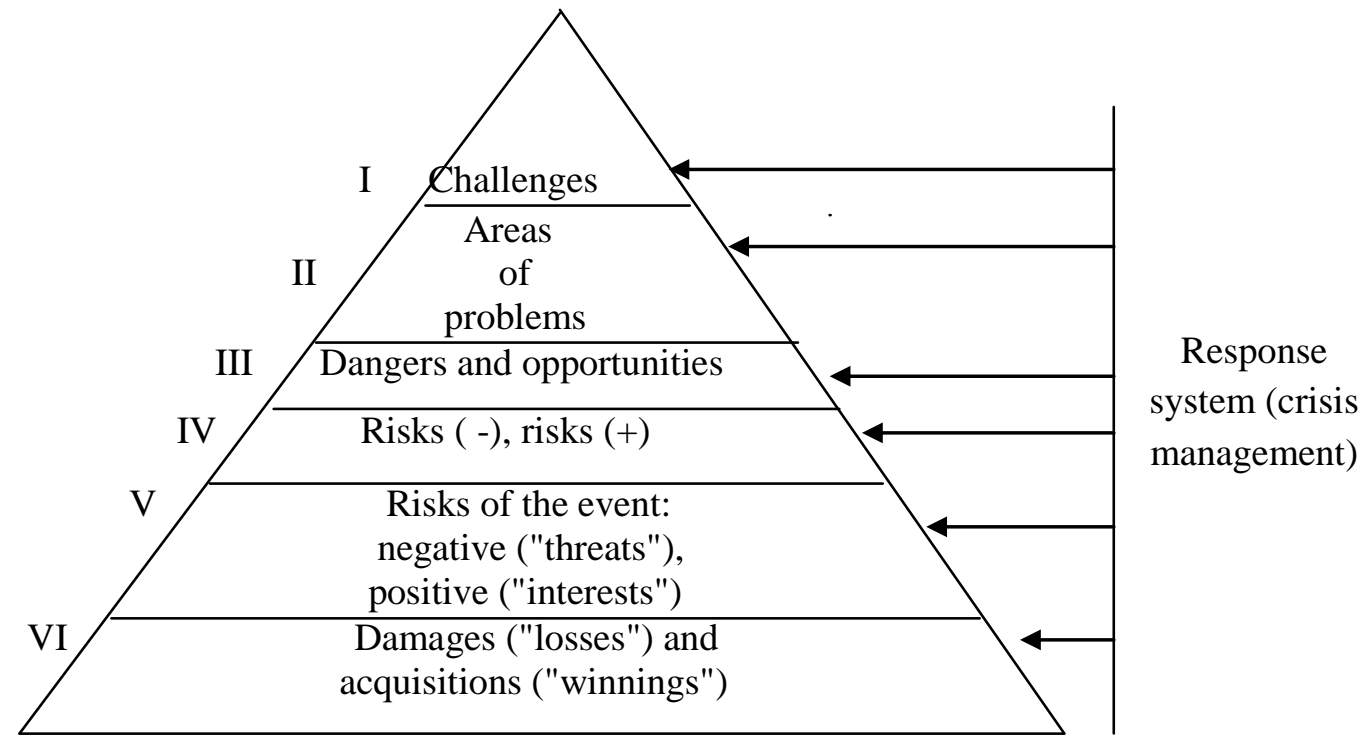

Fig. 1. The place of "challenge" in the security system ("security pyramid")

Consider the place of the category of "challenge" in the system of national interests.

"Challenges" and "interests" in the system of national security are closely interrelated. Undoubtedly, "interest" is defined, on the one hand, as causality of the actions of individuals, the social community 
(professional groups, classes, nations) and their social behavior, and on the other hand, external influences, including challenges as new dangers threats), and new opportunities.

In Fig. 2 shows the scheme of the dual effect of the "challenge", along with other factors (national idea, national values, the country's genetic code, etc.), on national interests, which was considered in $[10, p$. 12].

Challenging the system is a subjective change of at least one of the system parameters (the challenge subject), if it generates the probability of object change of other parameters of the system.

The system is defined by three parameters [13]:

- attributive concept, responsible for the properties (gradation) of the system;

- relational concept, responsible for internal relations (structure) in the system;

- the substrate responsible for identifying the system.

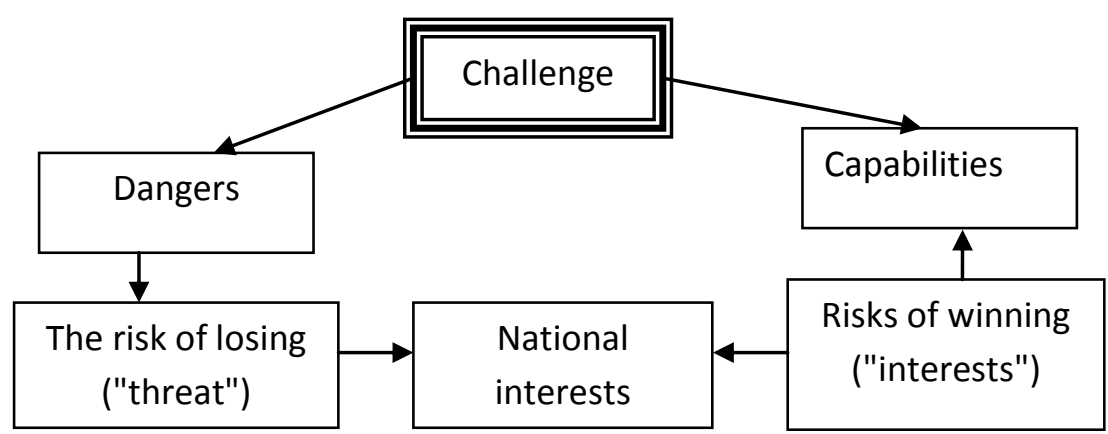

Fig. 2. Axiomatic model of the impact of the challenges of producing risks on the national interests of the state

The challenge can be formed not necessarily negative for the system by degradation, destructuring, deidentification, that is, the challenge can be positive or negative, depending on the expected synergistic effect.

A negative challenge is a threat. In general, the challenge is prerequisite to development - evolution, crisis, catastrophe (degeneration).

For challenges to socio-ecological and economic systems, we also apply the second postulate of I.V. Bestuzhev-Lada [14, p. 115], who argues that the quasi-elemental nature, that is, the practical uncontrollability of the vast majority of social processes or phenomena that can in principle be governed, allows us to refer to them in a certain sense as natural phenomena and to a certain extent abstract from the fundamental possibility of their modifying by means of control that substantially simplifies and facilitates both trend analysis and trend optimization, maximally revealing the great scientific potential of technological forecasting, that orientating not unconditional prediction, and to improve the effectiveness of decisions by purely conventional predictions as to "weighing" the consequences of proposed solution".

In the final part of this development, we consider it necessary to focus on the need to expand and deepen the theoretical and methodological studies of the problems of "challenges and risks" in the context of the development of the theory of national security (TNB). This formulation of the question is predetermined by the fact that the "challenge" and "risk" are actually the basic categories of the TNB. As is known, the conceptual-categorial apparatus is the initial basis of any theory. In this plan, we formulate a systemparametric model of the concept-categorical basis of the TNB, which is presented in The construction of this model is based on the ideas of the parametric general theory of systems [13], which we mentioned earlier. This theory of systems, using the so-called language of ternary description (from the position of "thing", "properties", "relations") allows solving the following problems within the framework of matrix-incidence analysis:

the qualitative account of the non-linearity of complex processes by comparing the variants by using several criteria;

choosing the best option from the set of possible options.

Conclusions and further researches directions. Summarizing the above, it is possible to formulate the main applied essence of the concept-categorical construction of the "challenge" in the socio-ecological and economic context, which has multiple dimensions. 
1) In a broad sense, the "challenge" should be considered in the following sense:

- subjective cumulative, purposeful deterministic or accidental economic, social, environmental manifestations and other unexpected changes in social development that can lead to positive or negative synergistic subject-object effects;

\begin{tabular}{|c|c|c|}
\hline & National security & \\
\hline & \multicolumn{2}{|c|}{ System Parametric Concepts } \\
\hline $\begin{array}{c}\text { Substrate (subjective) } \\
\text { concept ("category thing") }\end{array}$ & $\begin{array}{c}\text { Attributive (object) } \\
\text { concept ("category of } \\
\text { property") }\end{array}$ & $\begin{array}{l}\text { Relational concept (the } \\
\text { category of subject-object } \\
\text { "relations") }\end{array}$ \\
\hline \multirow{2}{*}{$\begin{array}{l}\text { Challenges } \\
\text { Dangers }\end{array}$} & National security & $\begin{array}{c}\text { Organization of the national security } \\
\text { system }\end{array}$ \\
\hline & National interests & Control national security \\
\hline Threats & National values & \multirow{2}{*}{$\begin{array}{l}\text { The concept (strategy) of national } \\
\text { security }\end{array}$} \\
\hline Risks & National ideology & \\
\hline \multirow[t]{2}{*}{ Eftects } & & \multirow{2}{*}{$\begin{array}{l}\text { Regulatory and Legal Regulation of } \\
\text { National Security }\end{array}$} \\
\hline & National Idea & \\
\hline
\end{tabular}

Fig. 3. " Challenge" in the system of the system-parametric classification of national security

- it is also subjectively formulated new ideas, projects (programs), causing new serious transformation processes, changes in objects;

- these are new dangers (threats), new opportunities that affect the essential (root) interests of communicatively dependent subjects of economic, social, environmental and other relations and require an adequate and, as a rule, an urgent response to a new situation on the part of the facility.

2) Assessment of the challenges provides an opportunity to identify emerging problems of possible risk events and to search for possible effective solutions. The problem of "challenges" as a very important scientific and applied problem requires the expansion and deepening of research.

3) The "Challenge" should be considered as a fundamental category both of the theory of national security and of the theory of risks (riskology), within the framework of which the theoretical, methodological and applied tasks of ensuring the protection of the vital interests of man and citizen, society and the state, prevention and neutralization real potential threats to national interests.

\section{ЛИТЕРАТУРА}

1. Стратегія національної безпеки України в контексті досвіду світової спільності: зб. ст. за матер. між народ. конф. / Гол. ред.. О.Ф, Белов. - К.: «Сатсанга», 2001. - 224 с.

2. Украина европейская безопасность. Международный научный семинар в Одессе 22-25 ноября 1996 г. (сокращенное изложение аудизаписи). - Одесса: Логос, 1997. - 56 с.

3. Горбулін В.П. Національна безпека: порядок денний для України / В.П. Горбулін, О.Ф. Белов, О.В. Литвиненко. - К.: ВД «СТИЛОС», 2009. - 126 с.

4. Концепція (Основы государственной политики) национальной безопасности Украины (Утверждена Постановлением Верховной Рады Украины, 16 января 1997 г. № 3/97-ВР) // Голос Украины, 1997. - № 19. - С. 5- 6. 
5. Об основах национальной безопасности Украины : Закон Украины от 19 июня 2003 г. № 964-IV / Відомості Верховної Ради України. Офіційне видання. - 2003. - № 39. - С. 1202 - 1211.

6. Стратегія національної безпеки України [Електронний ресурс]. - Режим доступу: http:www.prszsdent.gov.ua/documents5728.html.

7. Ліпкан В.Л. Управління системою національної безпеки України / В.А Лііпкан. - К.: КНТ, 2006. $-68 \mathrm{c}$.

8. Ліпкан В.А. Національна безпека України: навчальний посібник. - К.: КНТ, 2009. - 576 с.

9. Дергачев В.А. Геополитический словарь-справочник. - К.: КНТ, 2009. - 592 с.

10.Буркинский Б.В. Методологические и прикладные основы исследования национальных и региональных интересов ( социо-эколого-экономический контекст) / Б.В. Буркинский, В.Н. Степанов. - Одесса: ИПРЭЭИ НАН Украины, 2011. - 72 с.

11.Петренко И. Индикативная система общей безопасности хозяйствующего субъекта / И. Петренко // Вопросы экономики. - 2008. - № 1. - С. 149-154.

12.Степанов В.Н. К вопросу формирования теоретико-методологического базиса изучения проблем национальной, в том числе экономико-экологической безопасности // Природные и природно-техногенные риски береговой зоны морей. Материалы международной конференции, г. Одесса. 7-11 сентября 2008 г. - Одесса: ИПРЭЭИ НАН Украины, 2008. - С. 125-126.

13.Уемов А.И. Основы формального аппарата параметрической общей теории систем // Системные исследования. Методологические проблемы: Ежегодник. - 1984. - М.: Наука, 1984. - С.

14.Бестужев-Лада И.В. Будущее предвидимо, но не предсказуемо: эффект Эдипа в социальном прогнозировании / И.В. Бестужев-Лада // Проблемы предсказуемости / Под ред. Ю.А. Кравцова. - М.: Центрком, 1997. - С. $211-220$.

\section{REFERENCE}

1. Stratehiia natsionalnoi bezpeky Ukrainy v konteksti dosvidu svitovoi spilnosti: zb. st. za mater. mizhnarod. konf. [The Strategy of National Security of Ukraine in the Context of the Experience of the World Community: a collection of articles on materials of the international. conf.]. (2001). K.: «Satsanga», 224 [in Ukranian].

2. Ukraina yevropeyskaia bezopasnost. Mezhdunarodnyi nauchnyy seminar v Odesse 22-25 noiabria 1996 g. (sokrashchennoie izlozhenie audizapisi) [Ukraine's European security. International Scientific Seminar in Odessa on November 22-25, 1996 (shortened presentation of audio recording)]. (1997). Odessa: Logos, 56 [in Russian].

3. Gorbulin, V.P., Belov, O.F.\&Litvinenko, O.V. Natsionalna bezpeka: poriadok dennyi dlia Ukrainy [National Security: Agenda for Ukraine]. (2009). K.: VD «STILOS», 126 [in Ukranian].

4. Kontseptsiia (Osnovy gosudarstvennoi politiki) natsionalnoi bezopasnosti Ukrainy : Postanovlenie Verkhovnoi Rady Ukrainy ot 16 yanvaria 1997 g. № 3/97-VR) [Concept (Fundamentals of State Policy) of National Security of Ukraine : Resolution of the Verkhovna Rada of Ukraine, January 3, 1997 No. 3/97-BP)]. (1997). Golos Ukrainy, 19, 5-6 [in Russian].

5. Ob osnovakh natsionalnoi bezopasnosti Ukrainy Zakon Ukrainy ot 19 iyunia 2003 g. № 964-IV [On the Fundamentals of National Security of Ukraine The Law of Ukraine of June 19, 2003 No. 964-IV]. (2003). Vidomosti Verkhovnoi Rady Ukrainy. Ofitsiine vydannia - Information from the Verkhovna Rada of Ukraine. Official edition, 39, 1202-1211[in Ukranian].

6. Stratehiia natsionalnoi bezpeky Ukrainy (Zatverdzheno Ukazom Prezydenta Ukrainy vid 12 liutoho 2007 r. № 105/2007) [Strategy of National Security of Ukraine (Approved by Decree of the President of Ukraine dated February 12, 2007 No. 105/2007)]. (2007). www.prszsdent.gov.ua/documents5728.html. Retrived from: http:www.prszsdent.gov.ua/documents5728.html.

7. Lipkan, V.A. (2006). Upravlinnia systemoiu natsionalnoi bezpeky Ukrainy [Management of the National Security System of Ukraine]. K.: KNT, 68 [in Ukranian].

8. Lipkan, V.A. (2009) Natsionalna bezpeka Ukrainy: navchalnyi posibnyk [National Security of Ukraine: a manual]. K.: KNT, 576 [in Ukranian].

9. Dergachev, V.A. (2009). Geopoliticheskii slovar-spravochnik [Geopolitical dictionary-reference]. K.: KNT, 592 [in Ukranian]. 
10. Burkiknskii, B.V., Stepanov, V.N. (2001). Metodologicheskie i prikladnie osnovy issledovaniia natsionalnykh i regionalnykh interesov (sotsio-ekologo-ekonomicheskii kontekst) [Methodological and applied principles of research of national and regional interests (socio-ecological and economic context)]. Odessa: IPREEI NAN Ukrainy, 72.

11. Petrenko, I. (2008). Indikativnaia sistema obshchei bezopasnosti khoziaistvuiushchego subyekta [Indicative system of general security of an economic entity]. Voprosy ekonomiki - Issues of economics. 1, 149-154 [in Russian].

12. Stepanov, V.N. (2008). K voprosu formirovaniia teoretiko-metodologicheskogo bazisa izucheniia problem natsionalnoi, $\mathrm{v}$ tom chisle ekonomiko-ekologicheskoi bezopasnosti [To the question of the formation of the theoretical and methodological basis for studying the problems of national, including economic and environmental security]. Prirodnye i prirodno-tekhnogennye riski beregovoi zony morei. Materialy mezhdunarodnoy konferentsii, g. Odessa. 7-11 sentyabrya $2008 \mathrm{~g}$. - Natural and naturaltechnogenic risks of the coastal zone of the seas. Proceedings of the International Conference, Odessa. September 7-11, 2008. Odessa: IPREEI NAN Ukrainy, 125-126 [in Russian].

13. Uyemov, A.I. (1984). Osnovy formalnogo apparata parametricheskoi obshchei teorii system [Fundamentals of the formal apparatus of the parametric general theory of systems.]. Sistemnye issledovaniia. Metodologicheskiie problemy: Yezhegodnik - System studies. Methodological problems: Yearbook. M.: Nauka, 1984 [in Russian].

14. Bestuzhev-Lada, I.V. (1997). Budushcheie predvidimo, no ne predskazuemo: effekt Edipa v sotsialnom prognozirovanii. Problemy predskazuemosti [The future is foreseeable, but not predictable: the Oedipus effect in social forecasting. Predictability problems]. M.: Tsentrkom, 211-220 [in Russian]. 